\title{
The Effectiveness of Using Blended Learning with Google Classroom and Zoom Media on Students' Understanding
}

\author{
Wasti Reviandani ${ }^{1}$ \\ ${ }^{1}$ Management Study Program, Faculty of Economics and Business \\ Universitas Muhammadiyah Gresik, East Java, Indonesia \\ reviandaniwasti@gmail.com
}

\begin{abstract}
ABSTRAK
Proses belajar mengajar merupakan inti dari pendidikan. Segala sesuatu yang telah diprogramkan akan dilaksanakan dalam proses belajar mengajar dimana diperlukan interaksi dan keterlibatan antara pendidik dan peserta didik dengan bahan sebagai medianya. Kegiatan mengajar pada tingkat strata 1 melibatkan pendidik yang disebut dosen dan mahasiswa yang disebut mahasiswa. Pada umumnya kegiatan pengajaran dilakukan secara offline yang melibatkan interaksi langsung antara dosen dan mahasiswa. Pada awal tahun 2021 mulai muncul rumor bahwa ada bencana global pandemi Corona Virus Disease (COVID -19), yang awalnya Indonesia menganggap virus Corona tidak mungkin masuk ke Indonesia. Namun, perkembangan virus begitu cepat. Indonesia akhirnya diumumkan pada awal Maret 2021 sebagai negara yang mengalami dampak bencana global akibat pandemi COVID-19. Penelitian ini ingin mengetahui seberapa efektif penggunaan blended learning dengan menggunakan google classroom dan zoom untuk meningkatkan pemahaman mahasiswa FEB Universitas Muhammadiyah Gresik. Penelitian ini merupakan penelitian kuantitatif dengan menggunakan hubungan klausa kausal, dengan menggunakan alat analisis SPSS versi 23.0. Hasil yang diperoleh dari penelitian ini adalah bahwa aplikasi Google Classroom dan Zoom secara parsial dan simultan berpengaruh positif signifikan terhadap pemahaman siswa
\end{abstract}

Kata kunci: Blended Learning, Google Classroom, Zoom, Pemahaman Siswa.

\begin{abstract}
The teaching and learning process is the core of education. Everything that has been programmed will be carried out in the teaching and learning process where interaction and involvement is needed between educators and students with materials as the medium. Teaching activities at the strata 1 level involve educators called lecturers and students called students. In general, teaching activities are carried out offline, which involves direct interaction between lecturers and students. At the beginning of 2021, rumors began to appear that there was a global disaster of the Corona Virus Disease (COVID -19) pandemic, which initially Indonesia considered that the Corona virus was impossible to enter Indonesia. However, the development of the virus is so fast. Indonesia finally announced in early March 2021 as a country experiencing the impact of the global disaster due to the COVID-19 pandemic. This study wants to find out how effective it is to use blended learning by using google classroom and zoom to improve the understanding of FEB students at Muhammadiyah University of Gresik. This research is a quantitative research using causal clause relationship, using SPSS version 23.0 analysis tool. The results obtained from this study are that the Google Classroom and Zoom applications partially and simultaneously have a significant positive effect on student understanding
\end{abstract}

Key words: Blended Learning, Google Classroom, Zoom, Student understanding

\section{INTRODUCTION}

Teaching and learning process is the core of education. Everything that has been programmed will be implemented in the teaching and learning process where interaction and involvement is required between educators and students with materials as the medium. Teaching activities at the strata 1 level involve educators called lecturers and students called students. In general, teaching activities are 
carried out offline, which involves direct interaction between lecturers and students.

At the beginning of 2021, rumors began that there was a global disaster of the pandemic, Coronavirus appear Disease (COVID 19)which initially Indonesia considered that the Corona virus was impossible to enter Indonesia. However, the development of the virus is so fast. Indonesia was finally announced in early March 2021 as a country experiencing the impact of the global disaster due to the COVID19 pandemic.

The Covid-19 virus has hit 215 countries in the world, providing its own challenges for educational institutions, especially universities. To fight Covid-19, the government has banned crowds, social distancing and physical distancing, wearing masks and always washing hands. Through the Ministry of Education and Culture, the Government has prohibited universities from conducting face-to-face (conventional) lectures and ordered them to hold lectures or learning online (Kemendikbud Dikti Circular Letter No. 1 of 2021). The government takes special policies related to the teaching and learning process at all levels of education. This policy is contained in Circular Letter number 3 of 2021 Minister of Education and Culture Nadiem Anwar Makarim regarding the implementation of education during the Covid-19 emergency. The learning process from home is generally in the form of online learning (online). According to Moore, Dickson-Deane \& Galyan (2011) learning online learning that uses the internet network with accessibility, connectivity, flexibility and the ability to bring up various types of learning interactions. In the process, actually this learning model has been regulated in PERMENDIKBUD No. 22 of 2016 concerning Standards Process With the following principles:

a. From students being told to students finding out

b. From the teacher as the only source to learning based on various sources

c. From a textual approach to a process as a strengthening of the scientific approach d. From content-based learning to learning competency-based

e. From the learning partial towards an integrated learning

f. From learning that emphasizes a single answer to learning with multidimensional answers.

g. Learning that applies the principle that anyone is a teacher, anyone is a student and anywhere is a class.

Regarding the learning process from home which is carried out online/remotely to provide a meaningful learning experience for students, the learning process requires affordable online learning media for all undergraduate students of FEB University of Muhammadiyah Gresik. Jamaluddin, D., Ratnasih, T., Gunawan, H., \& Paujiah, E. (2021) stated that online learning has its own strengths, challenges and obstacles.

Students in this era are often called the net generation where they only need to move the mouse on the board or just touch the computer screen and can enter and leave the cyber world without having to leave the house. The net generation expresses their freedom more to the world so that they feel more considered by the world around them (Gunawan \& Sunarman, 2018). One way that can be used to carry out the online learning process is by using Google Classroom and Zoom. Utilization of Google Classroom can be through multiplatform, namely through computers and through mobile devices. Through the Google Classroom application, it is assumed that learning objectives will be more easily realized and full of meaning. Therefore, the use of Google Classroom actually makes it easier for teachers (lecturers) to manage learning and convey information precisely and accurately to students (Hakim, 2016). Through learning with blended learning, students feel comfortable and active in constructing their knowledge. Lecturers can take advantage of various features found in Google Classroom such as assignments, grading, communication, time-cost, archive course, mobile application, and privacy as well as lecturers can give assignments and directly 
give grades to students. Likewise with the Zoom application where applications can conduct remote conferences by combining video conferencing, online meetings, chat, to mobile collaboration.

Learning can be combined between the Google classroom method and Zoom media or often called Blended Learning. This research is expected to provide a solution to the method that has been applied in the classroom, namely the conventional method where the lecturer dominates the activities learning either by the lecture method or the assignment method. The implementation of learning with Google Classroom makes it easier to evaluate the implementation of the teaching and learning process both in the classroom and outside the classroom. Each learning method must contain the formulation of the organization of lesson materials, delivery strategies, and management of activities by taking into account the factors of learning objectives, learning barriers, and characteristics of students, in order to obtain effectiveness, efficiency, and attractiveness of learning (Miarso, 2004). The importance of implementation in e-learning-based learning with google classroom and zoom media, so this study aims to identify the effectiveness of google classroom and zoom-based learning.

Research by Ali Sadikin, Afreni Hamidah (2021) who researched online learning in the midst of the Covid-19 outbreak. Based on the results of the study, it can be concluded that the results of the study indicate that students have the facilities and infrastructure to carry out online learning. Online learning is effective for overcoming learning that allows lecturers and students to interact inclasses virtual classes that can be accessed anywhere and anytime.

Ferdiana, Suci (2021) conducted research at the Surabaya College of Health Sciences on Student Perceptions about the Use of Online Media. The types of media used include Google classroom \& meeting, Zoom, WhatsApp Group, Kahoot, Youtube and Quizizz with the highest frequency of using Moodle at $43 \%$ and the lowest frequency of using Quizizz at $2 \%$.
Student perceptions of preferred and disliked media with the results of the top 3 most preferred media being WhatsApp Group at $41.7 \%$, Zoom $28.2 \%$ and Google classroom \& meeting at $8.7 \%$. and the top 3 least liked media are Zoom by $53.4 \%$, Youtube by $15.6 \%$ and Moodle by $12.6 \%$.

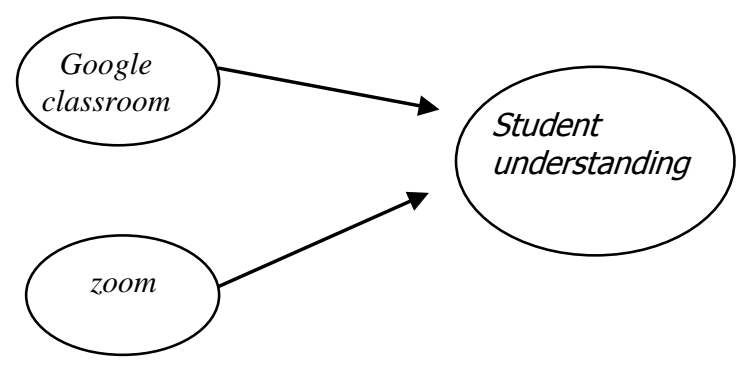

Figure 1: Conceptual Framework

Based on the above framework, the hypothesis proposed as a temporary answer to the problems posed in this study is as follows:

1. H1: The application Google Classroom has a significant effect on understanding of FEB studentsMuhammadiyah Gresik.

2. H2: The Zoom application has a significant effect on the understanding of FEB students Muhammadiyah Gresik.

3. H3: The Google Classroom and Zoom applications together have a significant effect on the understanding of FEB students Muhammadiyah Gresik.

\section{METHODE}

The type of research used is descriptive quantitative research. This study is used to describe the effect of learning google classroom and zoom on student learning understanding causally. The(independent variable independent variable) of this study are the variables of the use of google classroom (X1) and the use of zoom (X2) and the quality of student knowledge (Y).

The population is a generalization area consisting of objects/subjects that have certain qualities and characteristics determined by researchers to be studied and then drawn conclusions (Sugiyono, 2011:80). The 
population in this study were FEB students, Muhammadiyah University of Gresik. While the sample according to Sugiyono (2011:81) is part of the number and characteristics possessed by the population. So that the sample is part of the existing population, so it is based on existing considerations. In this sampling technique, the writer uses purposive sampling technique. Sugiyono (2011: 84) explains that purposive sampling is a sampling technique with certain considerations. The respondents' criteria for this study were all active students studying at FEB, Muhammadiyah University of Gresik. The questionnaire instrument in this study was made using four alternative categories of answers, namely: Score Strongly Agree 4 Agree 3 Disagree 2 Strongly Disagree 1

Techniques For data analysis techniques using validity and reliability tests using statistical methods supported by computer software/software using SPSS (Statistical Program for Social System) version 17.0. Validity test is used to measure whether a questionnaire is valid or not. A questionnaire considered valid if the questions in the questionnaire were able to reveal something that will be measured by questionnaire the (Ghozali, 2005: 45). If the valuecount is greater than rtable, then the statement or indicator is declared valid. Reliability is a tool to measure a questionnaire which is an indicator of a variable. A questionnaire is said to be reliable or reliable if one's answer to the statement is consistent. According to Ghozali (2007:41), if the value of Cronbach's Alpha > 0.60 then the indicator given to the respondent is said to be reliable.

Based on the formulation of the research problem, the data analysis technique used in this study is correlation analysis and hypothesis testing using statistical methods supported by computer software using the SPSS version 17.0 program. Classical Assumption Test In the use of multiple linear regression analysis, there are assumptions that must be met so that the regression model gives unbiased results. Normality Test The normality test aims to test whether in the regression model, the confounding or residual variables have a normal distribution. If this test is violated, the statistical test becomes invalid for a small sample size. One way to detect whether the residuals are normally distributed or not is by graphical analysis, namely by looking at the normal plot graph that compares the observation data with a distribution that is close to a normal distribution. To detect the normality of the data can be done with the Kolmogorov-Smirnov test to be more accurate (Ghozali, 2007: 107). Linearity Test, This test was conducted to determine whether the form of influence between the independent variable and the dependent variable was linear. The linearity test used in this calculation uses the $\mathrm{F}$ test through the ANOVA formula. Analysis Multiple Linear RegressionMethods of data analysis used in this research is multiple linear regression analysis (MultipleLinear Regression Analysis )is used for regressing simultaneously between the independent and the dependent variable.

\section{RESULTS AND DISCUSSION Results}

This research was conducted on students of the Faculty of Economics and Business, University of Muhammadiyah Gresik. Questionnaires have been distributed to students of study Accounting, Management, and Entrepreneurship Programs via google form. The questionnaires that returned were 124 questionnaires from students in semester 1 to semester 7. The results of the questionnaire obtained the characteristics of respondents who had male sex as many as $25.8 \%$ of respondents or $25.8 \%$, while women were 93 respondents or $74.2 \%$. Based on these data, the majority of respondents are female respondents.

For the distribution of frequency of the variable using the google classroom application (X1), it is known that from 124 respondents the average answer is at 3.08 intervals, it is said that the average indicator on the variable use of the google classroom application is strong. For the strongest indicator is on $\mathrm{X} 1.5$, the display 
of Google Classroom is very clear and easy to understand. While the lowest indicator is on X1.7, namely I have never experienced a system failure when completing tasks with Google Classroom.

For the distribution of the Variable Frequency of Use of the Zoom Meeting Application (X2), it is known that from 124 respondents the average answer is at 2.96 intervals, it is said that the average indicator on the variable of using the Zoom application Meeting is session. For the indicator strongest $\mathrm{X} 1.5$, Zoom meeting is easy to use. While the lowest indicator is on X1.7, namely I find it not difficult when checking whether the tasks I have collected have been sent.

For the distribution of frequency the Variable Effectiveness of Student Understanding (Y) it is known that from 124 respondents the average answer is at intervals of 2.92 , it is said that the average indicator on the variable using the zoom application meeting is moderate. For the strongest indicator is Y1.2, the lecturer gives assignments and materials. through Google Classroom and the zoom meeting application according to RPS. While the lowest indicator is at Y1.3, namely students feel motivated to learn with the Google Classroom and zoom meeting application.

Validity Testing on Variables Using Google Classroom Applications

It is known that the Pearson correlation coefficient (Rcount) on each item of the variable statement of the Use of Google Classroom Applications is greater than the value of $r$ table $=0.147$, so it can be concluded that each statement item is used to measure the Google Application Usage variable. Classroom can be said to be valid and can be used in further analysis.

Validity Testing on the Zoom Meeting Application Variable

It is known that the correlation coefficient Pearson (Rcount) in each item of the Zoom Application Usage variable statement is greater than the value of $r$ table $=0.147$, thus it can be concluded that each statement item is used to measure the Zoom Application Usage variable. can be said to be valid and can be used in further analysis.

Validity Testing on Student Understanding Effectiveness Variables

It is known that the correlation coefficient Pearson (Rcount) on each statement item of variable the effectiveness student understanding is greater than the value of $r$ table $=0.147$, thus it can be concluded that each statement item is used to measure the variables. effectiveness of student understanding can be said to be valid and can be used in further analysis.

Reliability test

Known that the value of Cronbach alpha in each variable of the use of social media is greater than the critical value of 0.6. So it can be concluded that the variables of social media are reliable/consistent and can be used in further analysis.

\section{Normality Test}

The results of the normality test in this study can be seen from the following graph: (normality). Data can be said to be normally distributed if the curve on the graph follows the shape of a bell (bell).

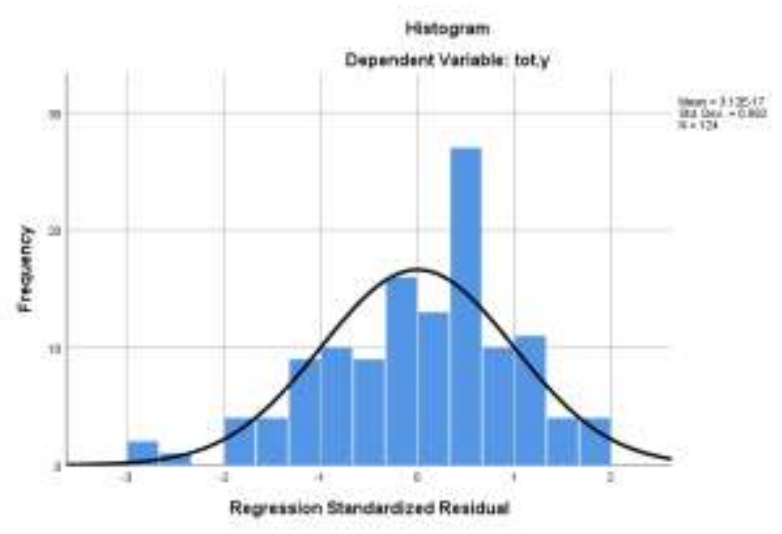

Figure 2: Normality Test Graph

In the graph above, it can be seen that the distribution of data has a curve that can be 
considered bell-shaped. So it can be concluded that the data is normally distributed.

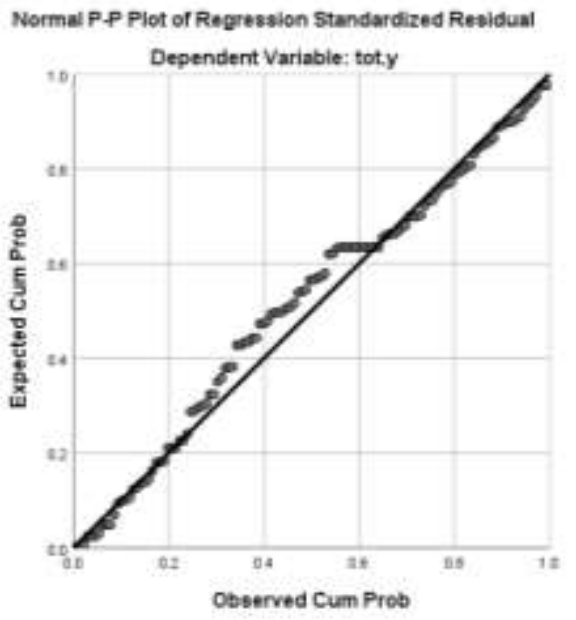

Figure 3: Normality Test Graph

Detection of normality can be seen from the spread of data (points) on the diagonal axis on the graph. If the data spreads around the diagonal line and follows the direction of the diagonal line, then the regression model meets the assumption of normality. In the graphic above, it can be seen that the data spreads around the diagonal line, and follows the direction of the diagonal line, so it can be said that the regression model has met the assumption of normality so that it is suitable for further analysis.

Multicollinearity

The results of the multicollinearity test can be seen from the following table:

Table 1: Multicollinearity Test

\begin{tabular}{|c|c|c|c|c|}
\hline & & (X1) & (X2) & $\begin{array}{c}\text { effectiveness } \\
\text { of student } \\
\text { understandin } \\
\mathrm{g}(\mathrm{Y})\end{array}$ \\
\hline \multicolumn{2}{|l|}{$\mathrm{N}$} & 171 & 171 & 171 \\
\hline \multirow{2}{*}{$\begin{array}{l}\text { Normal } \\
\text { Parameters }{ }^{\mathrm{a}, \mathrm{b}}\end{array}$} & Mean & 20.3684 & 24.0936 & 20.1696 \\
\hline & $\begin{array}{l}\text { Std. } \\
\text { Deviati } \\
\text { on }\end{array}$ & 2.58706 & 3.19789 & 3.32732 \\
\hline \multirow[t]{3}{*}{$\begin{array}{l}\text { Most Extreme } \\
\text { Differences }\end{array}$} & $\begin{array}{l}\text { Absolut } \\
\mathrm{e}\end{array}$ & .088 & .097 & .129 \\
\hline & Positive & .088 & .090 & .092 \\
\hline & $\begin{array}{l}\text { Negativ } \\
\mathrm{e}\end{array}$ & -.087 & -.097 & -.129 \\
\hline \multicolumn{2}{|c|}{ Kolmogorov-Smirnov Z } & 1.148 & 1.271 & 1.681 \\
\hline \multicolumn{2}{|c|}{ Asymp. Sig. (2-tailed) } & .143 & .079 & .067 \\
\hline
\end{tabular}

a. Test distribution is Normal.

b. Calculated from data.

It is known that the KS value of the use of the Google Classroom application is 1.148 with a probability of 0.143 , the use of the Zoom application is 1.271 with a probability of 0.79 , and the effectiveness of student understanding is 1.681 with a probability 0.67 (Asymp.Sig (2tailed). The data requirements are called normal if the probability or $\mathrm{p}>0.05$ in the normality test with KS. Therefore, the $\mathrm{p}$ value of all variables $>0.05$, it is known that the residuals are normally distributed.

Heteroscedasticity Test

If the independent variable is statistically significant affecting the independent variable, namely below $0.05 \quad(<0.05)$, then heteroscedasticity occurs. If there is no statistically significant independent variable affecting the independent variable, it is above 0.05 (>0.05), then there is no heteroscedasticity. A good regression model is a homoscedastic model.

Based on result then it can be seen that there is no statistically significant independent variable affecting the dependent variable, this can be seen from the probability of significance above 0.05 . So it can be concluded that the model does not occur heteroscedasticity

Multiple Linear Regression Analysis

Multiple Linear regression was used to simultaneously regress between the independent variables Google Classroom application (X1) and Zoom Meeting Application (X2) with the dependent variable effectiveness of student understanding (Y).

Coefficient of Multiple Determination (R2)

The results of the calculation of the coefficient of multiple determination (R2) can be explained as follows: The regression coefficient of 0.134 states that if there are no variables using the Google Classroom Application and the Use of the Zoom 
Application, then the effectiveness of student understanding is 0.134 . The regression coefficient X1 of 0.414 states that each additional variable Classroom Use of Google Apps, then the effectiveness of student understanding will increase by 0,414 . The regression coefficientX2 of 0.534 states that each additional variable Zoom Application Usage, then the effectiveness of student understanding will increase by 0.534 .

The results of the calculation of the coefficient of multiple determination (R2) can be explained as follows: based on data processing results obtained, the $\mathrm{R}$ number is 0.801 (> 0.5) indicating that the correlation between the dependent variable on the effectiveness of student understanding and the two independent variables, namely the use of the Google Classroom application and the use of the Zoom application, is very strong. The number of $\mathrm{R}$ squares or the coefficient of determination is 0.642 . However, in this study, the number is used as Adjusted $\mathrm{R}$ Square because if the number of variables in this study is more than two, it is better to use Adjusted R Square. The Adjusted $\mathrm{R}$ Square number is 0.637 , this means that $63.7 \%$ of the variation of the variable effectiveness student understanding can be explained by the variables of the Google Classroom Application Usage and the Zoom Application Use, while the remaining $36.3 \%$ is explained by other variables.

\section{Hypothesis Test}

Test Partial

The value variable Classroom Use of Google Apps (X1)is approximately 3.765 at a significance level of less than $5 \%$ that is equal to 0.00 . Based on the probability, it can be concluded that the Google Classroom Application Usage variable (X1) has a significant influence on the variable effectiveness of student understanding(Y). valueT variable Application Usage Zoom (X2)is approximately 5.146 at a significance level of less than $5 \%$ that is equal to 0.00 .probability-based, Itsit can be concluded that the use of Application variables Zoom (X2)have a significant effect on the variable the effectiveness of students' understanding

F Test

Testing the regression hypothesis together ( $F$ test) is shown to determine the effect of the two independent variables simultaneously on the dependent variable in a model. The criteria for this F test are: if the results of the F statistic at a significant level of alpha $=5 \%$ obtained a significance value of $\mathrm{F}>0.05$, it means that the independent variables simultaneously have no significant effect on the dependent variable. If the results of the $\mathrm{F}$ statistic at a significant level of alpha $=5 \%$ obtained a significance value of $\mathrm{F}<0.05$, it means that the independent variables simultaneously have a significant influence on the dependent variable. In the table it can be seen that the calculated $F$ value of the regression results is 150.364 with a significance level of 0,00 so that there is a simultaneous significant effect of the independent variable the use of the Google Classroom Application (X1) and the use of the Zoom application (X2) on the dependent variable of the effectiveness of student understanding (Y). Thus, according to the hypothesis which states "it is suspected that the use of the Google Classroom application and the use of the Zoom application have a simultaneous and significant effect on the effectiveness of student understanding" the truth is accepted.

\section{Discussion}

The the following will discuss research findings on empirical data analysis in connection with the proposed hypothesis, namely the effect of the use of the Google Classroom application and the use of the Zoom application on the effectiveness of student understanding.

The Influence of the Use of Google Classroom Applications on the Effectiveness of Student Understanding 
In the table it is a distribution variable known that from 124 respondents the average answer is at 3.08 intervals, it is said that the average indicator on the variable use of the Google Classroom application is strong. For the indicator strongest is on $\mathrm{X} 1.5$, the display of Google Classroom is very clear and easy to understand. While the lowest indicator is on X1.7, namely I have never experienced a system failure when completing tasks with Google Classroom. On the table The coefficient shows that the variable of Google Classroom Application Usage (X1) has a significant influence on the variable of effectiveness student understanding $(\mathrm{Y})$.

The Effect of Using Zoom Applications on the Effectiveness of Student Understanding

In the distribution table it is known that from 124 respondents the average answer is at 2.96 intervals, it is said that the average indicator on the variable using the Zoom Application meeting is moderate. For the indicator strongest X1. 5, Zoom meeting is easy to use. While the lowest indicator is on X1.7, namely I find it not difficult when checking whether the tasks I have collected have been sent. The Table coefficient shows that the Zoom Application Use variable (X2) has a significant influence on the variable effectiveness of student understanding (Y).

The Influence of the Use of Google Classroom Applications and the Use of Zoom Applications on the Effectiveness of Student Understanding In the table it is a distribution variable known that from the 124 respondents the average answer is at 2.92 intervals, it is said that the average indicator on the variable use of the Zoom Application meeting is moderate. For the indicator strongest is Y1. 2, namely Lecturers provide assignments and materials through Google Classroom and the Zoom meeting application according to the RPS. While the lowest indicator is at Y1.3, namely students feel motivated to learn with the Google Classroom and zoom meeting application, the simultaneous test table shows that the use of the
Google Classroom application and the use of the Zoom application have a simultaneous and significant effect on the effectiveness of student understanding.

\section{CONCLUSIONS}

From the results of data analysis and discussion, it can be concluded that the use of the Google Classroom application has a significant influence on the effectiveness of UMG students' understanding, the use of the Zoom application has a significant influence on the effectiveness of UMG students' understanding, the use of the Google Classroom application and the use of the Zoom application together. The same has a significant influence on the effectiveness of UMG students' understanding. From the indicator weakest on the use of Google Classroom Applications, namely I experienced a system failure when completing assignments with Google Classroom, the author suggests giving a grace period in collecting online assignments, because it is related to the system. from the application Google classroom. Muhammadiyah University of Gresik as an education service provider is expected to be able to provide support to students in the form of training in the use of online learning media in the form of zoom and google classroom so that students are able to master the learning media

\section{REFERENCES}

Abdul Barir hakim. 2016. Efektifitas Penggunaan E-Learning Moodle, Google. Classroom Dan Edmodo. STIMIK ESQ Vol. 2, no. 1

Aden\&Tabah Heri. (2021) Efektifitas penerapan blended learning dalam upaya meningkatkan kemampuan akademik mahasiswa melalui jaringan schoology di masa pandemi. Jurnal pembelajaran matematika inovatid. Vol 3 no 5 septermber 2021. ISSN 2614-2155

Ali Sadikin \& Afreni Hamidah. (2021). "Pembelajaran Daring Di Tengah Wabah. 
Covid-19." Jurnal Ilmiah Pendidikan Biologi 6(2):214-24.

Anggia T. R., Kawet, L., \& Ogi, I. (2015). Analisis Pengaruh Strategi Promosi, Harga, Dan Kepuasan Terhadap Loyalitas Konsumen Surat Kabar Manado Post. Jurnal EMBA Vol.3 No.2 Juni 2015, Hal. 1041-1050.

Assegaft, Setiawan. 2017. Evaluasi Pemanfaatan Media Sosial Sebagai Sarana Knowledge Shering. Jurnal Manajemen Teknologi. Vol 16, No. 3, 2017. Hlm 271-293.

Bibi, Sarah. (2015). Efektivitas Penerapan Blended Learning Terhadap Tingkat Pemahaman Mahasiswa Mata Kuliah Algoritma Dan Pemrograman. Jurnal Pendidikan Informatika dan Sains, 4(2),274-286.

Fitri, Mellyana Eka Yan dan Chairoel Lucy. 2019. Penggunaan Media Sosial Berdasarkan Gender Tahap Prestasi Belajar Mahasiswa . Jurnal Benefita . Vol 4, No.1, Februari 2019. Hlm 162181.

Ghozali, Imam, 2007, Aplikasi Analisis Multivariate Dengan Program SPSS, Universitas Diponogoro, Semarang

Ghozali, Imam. 2005. Aplikasi Analisis Multivariate dengan SPSS. Semarang: Badan Penerbit UNDIP

Ghozali, Imam. 2005. Aplikasi Analisis Multivariate dengan SPSS. Semarang: Badan Penerbit UNDIP

Gunawan, F. I. \& Sunarman, S. G. 2018. Pengembangan Kelas Virtual dengan Google Classroom dalam Keterampilan Pemecahan Masalah (Problem Solving) Topik Vektor pada Siswa SMK untuk Mendukung Pembelajaran. Prosiding Seminar Nasional Etnomatnesia.

http://mangihot.blogspot.com/2017/04/pengerti an-twitter-dan-sejarahtwitter.html?m=1\%

https://databoks.katadata.co.id/datapublish/2019 /07/18/indonesia-pengguna-internetterbesar-ketiga-di-asia https://m.detik.com/inet/telecommunication/d4551132/ini-jumlah-pengguna internetindonesia-sepanjang-2018

https://websindo.com/indonesia-digital-2019media-sosial/

https://www.kompasiana.com/ariaindhi/597000 eded967e0aed056e12/fenomenayoutube-sebagai-media-penyiaran-dizaman-modern?page $=2$

Husamah. (2014). Pembelajaran Bauran (Blended Learning). Jakarta: Prestasi Pustaka.

Miarso, Yusuf hadi, Menyemai Benih Teknologi Pendidikan, Jakarta: Kencana. Prenada Media Group, 2004.

Moore, J. L., Dickson-Deane, C., \& Galyen, K. (2011). E-Learning, online learning, and distance learning environments: Are they the same? Internet and Higher Education, 14(2), 129-135. https://doi.org/10.1016/j.iheduc.2010.10. 001

Putri (2021) meneliti tentang Efektivitas Pola Daring melalui Video (Video Based Learning).

http://repository.unpas.ac.id/id/eprint/494 52

Sabran, \& Sabara, E. (2019). Keefektifan Google Classroom Sebagai Media Pembelajaran. OJS UNM

Sherlyanita, Astrid Kurnia dan Rakhmawati, Nur Aini. 2016. Pengaruh dan Pola Aktivitas Penggunaan Internet Serta Media Sosial Pada Siswa SMPN 52 Surabaya. Journal of Information Systems Engineering and Business Inyelligenc., Vol 2, No.1, April 2016.

Sjukur, Sulihin B. 2021. Pengaruh Blended Learning Terhadap Motivasi Belajar dan Hasil Belajar Siswa Tingkat SMK. Jurnal Pendidikan Vokasi. Vol. 2.

Sudjana (2005). Penilaian Hasil Proses Belajar Mengajar. Bandung: PT Remaja Rosdakarya.

Sugiyono (2011). Metode penelitian kuntitatif kualitatif dan R\&D. Alfabeta 
Sugiyono. 2011. Metode Penelitian Kuantitatif, Kualitatif dan R\&D. Bandung: Afabeta.

Wibisono, Taufik dan Mulyani, Yani Sri. 2018.

Analisis Dampak Penggunaan Media Sosial Terhadap Prestasi Akademik Pelajar Tingkat Sekolah Menengah Pertama. Jurnal Ekonomi Manajemen. Vol 4, No. 1, Mei 2018. Hlm. 1-7.

Widiastuti, Desi Kurna. 2014. Twitter Sebagai Media Alternatif Informasi Mublik. 